\title{
Technology in the African workplace: Introduction to the special edition
}

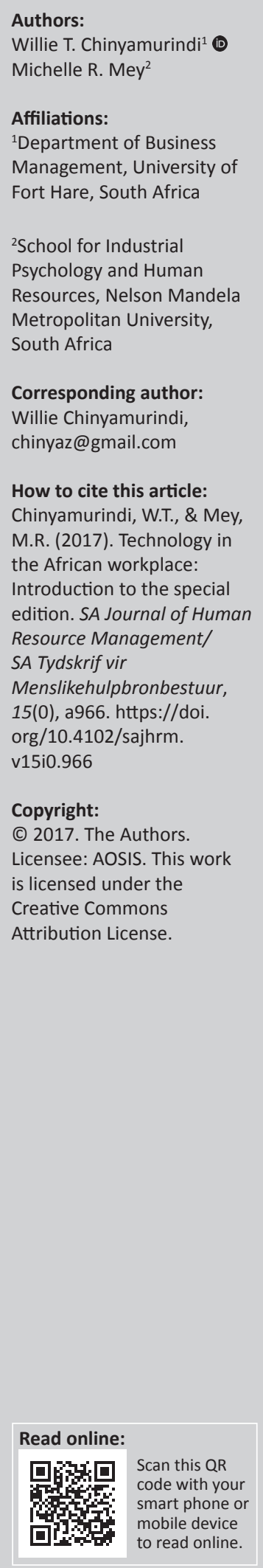

Authors:

Michelle R. Mey

Affiliations:

${ }^{1}$ Department of Business Management, University of

${ }^{2}$ School for Industrial Psychology and Human Metropolitan University,

Corresponding author: Willie Chinyamurindi, chinyaz@gmail.com

How to cite this article: the African workplace: Introduction to the special Resource Management/ SA Tydskrif vir Menslikehulpbronbestuur, org/10.4102/sajhrm. v15i0.966

Copyright:

Licensee: AOSIS. This work

is licensed under the

Creative Commons

Attribution License.
This special issue is dedicated to exploring the role of technology in the African workplace. Technology is argued to be an important driver within modern society, resulting in its popularity (Yuan, Raubal \& Liu, 2012). The popularity of technology is acknowledged especially on the African continent, given advancements in Information and Communication Technology (ICT) infrastructure (International Telecommunications Union, 2013). This also appears to link with Africa being acknowledged as having a young and growing population (Page, 2012). Given such a context, an organisational response is required that constantly seeks ways of gaining an advantage over competitors (Castaneda \& Toulson, 2013). The Human Resources Management (HRM) function exists as an important organisational capability through which this can be attained. It can be expected that within the domain of HRM, technology will have ramifications (positive and negative) for employees and subsequently on the overall performance of the organisation.

Parry (2011) argues for the use of technology in the workplace as affecting the HRM functionary and activities such as talent management, recruitment, selection, induction, socialisation, remuneration, compensation, training and development, performance management and career and knowledge management. This has led to the usage of terms such as electronic HRM (e-HRM), referring to 'a way of implementing HR strategies, policies and practices in organisations through a conscious and directed support of and/or with the full use of web-technology-based channels' (Ruel, Bondarouk \& Looise, 2004, p. 281), often resulting in organisations having more specialised HRM professionals (Tremblay, Patry \& Lanoie, 2008).

Despite this growth in the use of technology within the workplace, more empirical efforts are needed, especially within the African workplace and proving empirically that technology has an impact on productivity. We hope that this special issue ignites continued interest in this area of inquiry with both theoretical and practitioner ramifications. Our call appears supported also within the international press (e.g. Oostrom, Van der Linden, Born \& Van der Molen, 2013; Parry, 2011; Torrington, Hall \& Taylor, 2005). This can possibly create strategic linkages between the technology and the human aspect (Bondarouk \& Ruel, 2009; Strohmeier, 2007, 2009).

In this special issue, some key contributions are presented:

- Zikhona Dlaza and Willie Tafadzwa Chinyamurindi provide a book review of the book edited by Richard N. Landers and Gordon B. Schmidt titled Social media in employee selection and recruitment: Theory, practice and current challenges. This book appears relevant and poignant, especially given the growth in the popularity of social media even within the African context. Probably, the book will feature much in our African classroom and corporate context as part of ongoing discussion around the use of social media within the workplace.

- Andre Calitz, Paul Poisat and Margaret Cullen take a futuristic stance by focussing on the role and the use of collaborative robots in manufacturing. One of the salient findings of this paper is the sense of awareness by African businesses as to the use and implementation of Cobots. The challenge appears to be finding ways in which some form of co-existence can be created by a context in need of technological innovation while at the same time addressing the fears such as retrenchment.

- Continuing in the same vein are Paul Poisat and Michelle Mey, who in their paper explore e-HRM and its link to organisational productivity. The paper by the authors draws on a position of guided optimism that technology is not always a panacea to the challenges of modern organisations. Thus, due care and attention is needed when positioning the value (or the lack thereof) of technology in the modern organisation. 
- Liezel Cilliers, Willie Tafadzwa Chinyamurindi and Kim Viljoen explore the factors that influence the intention to use social media for work-related purposes at a South African higher education institution. Notably, the use of social media was found to serve a useful purpose in problem-solving and communication in the workplace. The paper challenges notions that may exist bemoaning the role of social media in the workplace.

\section{Acknowledgements}

The authors would like to express their gratitude to all the authors who contributed to this special edition.

\section{Competing interests}

The authors declare that they have no financial or personal relationships which may have inappropriately influenced them in writing this article.

\section{Authors' contributions}

W.T.C. and M.R.M. both acted as guest editors of the special edition. The introduction to the special edition was jointly written by them.

\section{References}

Bondarouk, T., \& Ruel, H. (2009). Electronic human resource management: Challenges in the digital era. International Journal of Human Resource Management, 20(3), 505-514. https://doi.org/10.1080/09585190802707235

Castaneda, D., \& Toulson, P. (2013). The value of human resources measurement in intellectual capital and knowledge sharing. Electronic Journal of Knowledge Management, 11, 226-234.

International Telecommunications Union. (2013). The world in 2013: ICT facts and figures. Retrieved October 20, 2014, from http://www.itu.int/en/ITU-D/Statistics/ Documents/facts/ICTFacts-Figures2013.pdf

Oostrom, J.K., Van der Linden, D., Born, M.P., \& Van der Molen, H.T. (2013). New technology in personnel selection: How recruiter characteristics affect the adoption of new selection technology. Computers in Human Behavior, 29, 24042415. https://doi.org/10.1016/j.chb.2013.05.025

Page, J. (2012). Youth, jobs and structural change: Confronting Africa's 'Employment Problem'. Tunisia, Tunis: African Development Bank.

Parry, E. (2011). An examination of e-HRM as a means to increase the value of the HR function. International Journal of Human Resources Management, 22(5), 11461162. https://doi.org/10.1080/09585192.2011.556791

Ruel, H., Bondarouk, T., \& Looise, J.K. (2004). E-HRM innovation or irritation: An empirical study in large five companies on web-based HRM. Management Review, $15,364-380$.

Strohmeier, S. (2007). Research in e-HRM: Review and implications. Human Resource Management Review, 17, 19-37. https://doi.org/10.1016/j.hrmr.2006.11.002

Strohmeier, S. (2009). Concepts of e-HRM consequences: A categorisation, review and suggestion. International Journal of Human Resource Management, 20(3), 528543. https://doi.org/10.1080/09585190802707292

Torrington, D., Hall, L., \& Taylor, S. (2005). Human resource management. Harlow: Financial Times.

Tremblay, M., Patry, M., \& Lanoie, P. (2008). Human resource outsourcing in Canadian organizations: An empirical analysis of the role of organizational characteristics, 19, 683-715. https://doi.org/10.1080/09585190801953699

Yuan, Y.M., Raubal, M., \& Liu, Y. (2012). Correlating mobile phone usage and travel behavior - A case study of Harbin, China. Computers, Environment and Urban Systems, 36(2), 118-130. https://doi.org/10.1016/j.compenvurbsys.2011.07.003 